\title{
The sss Colonization Gene of the Tomato-Fusarium oxysporum f. sp. radicis- lycopersici Biocontrol Strain Pseudomonas fluorescens WCS365 Can Improve Root Colonization of Other Wild-type Pseudomonas spp. Bacteria
}

\author{
Linda C. Dekkers, Ine H. M. Mulders, Claartje C. Phoelich, Thomas F. C. Chin-A-Woeng, \\ André H. M. Wijfjes, and Ben J. J. Lugtenberg \\ Leiden University, Institute of Molecular Plant Sciences, Clusius Laboratory, Wassenaarseweg 64, Leiden \\ 2333AL, The Netherlands \\ Accepted 16 June 2000.
}

\begin{abstract}
We show that the disease tomato foot and root rot caused by the pathogenic fungus Fusarium oxysporum f. sp. radicis-lycopersici can be controlled by inoculation of seeds with cells of the efficient root colonizer Pseudomonas fluorescens WCS365, indicating that strain WCS365 is a biocontrol strain. The mechanism for disease suppression most likely is induced systemic resistance. $P$. fluorescens strain WCS365 and $P$. chlororaphis strain PCL1391, which acts through the production of the antibiotic phenazine-1carboxamide, were differentially labeled using genes encoding autofluorescent proteins. Inoculation of seeds with a 1:1 mixture of these strains showed that, at the upper part of the root, the two cell types were present as microcolonies of either one or both cell types. Microcolonies at the lower root part were predominantly of one cell type. Mixed inoculation tended to improve biocontrol in comparison with single inoculations. In contrast to what was observed previously for strain PCL1391, mutations in various colonization genes, including sss, did not consistently decrease the biocontrol ability of strain WCS365. Multiple copies of the sss colonization gene in WCS365 improved neither colonization nor biocontrol by this strain. However, introduction of the sss-containing DNA fragment into the poor colonizer P. fluorescens WCS307 and into the good colonizer $P$. fluorescens F113 increased the competitive tomato root tip colonization ability of the latter strains 16- to 40-fold and 8- to 16-fold, respectively. These results show that improvement of the colonization ability of wild-type Pseudomonas strains by genetic engineering is a realistic goal.
\end{abstract}

Commercial application of fluorescent Pseudomonas spp. as biocontrol agents against a large group of plant pathogens

Corresponding author: B. J. J. Lugtenberg; Telephone: +31-71-5275063; Fax: +31-71-5275088; E-mail: Lugtenberg @ rulbim.leidenuniv.nl

Current address of L. C. Dekkers: MicroSafe B.V., Niels Bohrweg 1113, Leiden 2333CA, The Netherlands. can be hampered by their inconsistent performance in the field (Schroth and Hancock 1982). These inconsistencies are often accompanied by inefficient colonization of the plant root by the biocontrol strain (Schippers et al. 1987), suggesting that colonization is often the limiting factor for biocontrol.

To study colonization, we selected $P$. fluorescens strain WCS365 (Geels and Schippers 1983a, 1983b) as the most efficient root colonizer among a series of biocontrol strains (Brand et al. 1991). This strain is not antagonistic against a large number of fungal pathogens on antagonistic test plates under laboratory conditions (T. F. C. Chin-A-Woeng, unpublished data). However, strain WCS365 induces induced systemic resistance (ISR) in Arabidopsis thaliana ecotype Columbia, which thereby is protected against the pathogen $P$. syringae pv. tomato strain DC3000 (Gerrits and Weisbeek 1996). Therefore, we tested whether P. fluorescens WCS365 is also able to control tomato foot and root rot, the plant disease studied in our previous work (Chin-A-Woeng et al. 1998; Lugtenberg et al. 2000).

In order to unravel the molecular basis of root colonization, $P$. fluorescens WCS365 has been used for the generation of colonization mutants (Dekkers et al. 1998a, 1998b, 1998c; Lugtenberg and Dekkers 1999; Simons et al. 1997). One of the colonization mutants, strain PCL1233, was complemented for colonization by a wild-type DNA fragment containing a multicistronic transcription unit that comprises at least six open reading frames (ORFs) (Dekkers et al. 1998b). The fifth ORF of this DNA fragment, which is homologous to the site-specific recombinases Sss (Hofte et al. 1994), XerC (Colloms et al. 1990), FimB, and FimE (Dorman and Higgins 1987; Klemm 1986), was shown to be crucial for colonization (Dekkers et al. 1998b). This gene is thought to play a role in DNA rearrangements that regulate the transcription of a gene or a set of genes involved in the biosynthesis of cell surface components (Dekkers et al. 1998b). In a more general perspective, it is thought that lack of DNA rearrangements in mutant PCL1233 results in cells that are locked in a state unfavorable for competitive colonization (Dekkers et al. 1998b). 
In this article, we show that WCS365 is able to control tomato foot and root rot and describe how its colonization behavior on the tomato root is influenced by the presence of the antibiotic-producing biocontrol strain $P$. chlororaphis PCL1391. Moreover, we describe the effect of inactivated col genes, including sss, on biocontrol. Finally, we describe how the introduction of the sss operon into other Pseudomonas spp. affects the colonization abilities of these wild-type strains.

\section{RESULTS}

\section{Biocontrol by $P$. fluorescens WCS365 and by a mixture with $P$. chlororaphis strain PCL1391.}

Biocontrol experiments performed in an Fusarium oxysporum f. sp. radicis-lycopersici-tomato system showed that P. fluorescens WCS365 (Table 1) in all three experiments suppressed the disease in a statistically significant way (Table 2). P. fluorescens WCS365 showed similar biocontrol activity to PCL1391, a $P$. chlororaphis strain recently described to control tomato foot and root rot (Chin-A-Woeng et al. 1998). Considering the observation that both strains occupy similar sites on the tomato root and that both are efficient colonizers (Lugtenberg and Dekkers 1999), we studied how the strains behave on the root after they had been applied on the seedling as a mixture. In order to distinguish the strains, they were genetically marked with variants of green fluorescent protein.

Germinated tomato seedlings were inoculated with a 1:1 mixture of red fluorescent (DsRed) or enhanced cyan fluorescent protein (ECFP)-marked WCS365, and enhanced green (EGFP) or yellow (EYFP) fluorescent protein-marked $P$. chlororaphis PCL1391 (Bloemberg et al. in press). Using confocal laser microscopy on 1-week-old roots of sterile tomato plantlets, we observed that bacterial cells are mainly present as elongated stretches on indented areas, such as junctions between epidermal cells and the deeper parts of the epidermis on the root surface and on root hairs (Fig. 1). The highest numbers of bacteria and microcolonies were found at the root base (Fig. 1), whereas numbers of both bacterial cells and mi-

Table 1. Bacterial strains and plasmids used in this study

\begin{tabular}{|c|c|}
\hline Strains and plasmids & Characteristics and references \\
\hline \multicolumn{2}{|l|}{ Pseudomonas fluorescens } \\
\hline WCS365 & $\begin{array}{l}\text { Isolated from potato (Geels and Schippers 1983a, 1983b). Efficient colonizer of potato roots (Brand et al. 1991; } \\
\text { Glandorf 1992) and tomato roots (Simons et al. 1996). Causes induced systemic resistance in Arabidopsis } \\
\text { thaliana ecotype Columbia against Pseudomonas syringae pv. tomato (Gerrits and Weisbeek 1996). Bio- } \\
\text { control strain in a Fusarium oxysporum f. sp. radicis-lycopersici-tomato system (this article). }\end{array}$ \\
\hline WCS307 & $\begin{array}{l}\text { Isolated from potato (Geels and Schippers 1983b). Poor colonizer of potato roots (Brand et al. 1991; } \\
\text { Glandorf 1992) and tomato roots (Simons et al. 1996). }\end{array}$ \\
\hline F113 & $\begin{array}{l}\text { Biocontrol strain in a Pythium ultimum-sugar beet system (Shanahan et al. 1992). Good colonizer of tomato } \\
\text { roots (Simons et al. 1996). }\end{array}$ \\
\hline PCL1209 & $\begin{array}{l}\text { Mutant of } P \text {. fluorescens strain WCS365 impaired in the synthesis of the O-antigen of lipopolysaccharide and } \\
\text { in competitive tomato root tip colonization ( Dekkers et al. 1998a). }\end{array}$ \\
\hline PCL1210 & $\begin{array}{l}\text { Mutant of } P \text {. fluorescens strain WCS365 impaired in competitive tomato root tip colonization, in which a } \\
\text { mutation in a two-component system is responsible for the mutant phenotype ( Dekkers et al. 1998a). }\end{array}$ \\
\hline PCL1232 & $\begin{array}{l}\text { P. fluorescens WCS365 derivative harboring plasmid pMP5215 (Dekkers et al. 1998b) used for colonization } \\
\text { and biocontrol experiments (this article). }\end{array}$ \\
\hline PCL1233 & $\begin{array}{l}\text { Mutant of } P \text {. fluorescens strain WCS365 impaired in competitive tomato root tip colonization in which a } \\
\text { mutation in a site-specific recombinase is responsible for the mutant phenotype ( Dekkers et al. 1998b). }\end{array}$ \\
\hline PCL1269 & $\begin{array}{l}\text { Mutant of } P \text {. fluorescens strain WCS365 impaired in motility and in competitive tomato root tip colonization } \\
\text { (this article). }\end{array}$ \\
\hline PCL1391 & $\begin{array}{l}\text { Wild-type } P \text {. chlororaphis, producing phenazine-1-carboxamide and biocontrol strain of tomato foot and root } \\
\text { rot caused by F. oxysporum f. sp. radicis-lycopersici (Chin-A-Woeng et al. 1998). }\end{array}$ \\
\hline PCL1500 & $\begin{array}{l}\text { lacZ derivative of } P \text {. fluorescens WCS365, which is as efficient as the parental strain in colonizing the tomato } \\
\text { root tip (van der Bij et al. 1996). }\end{array}$ \\
\hline PCL1502 & $\begin{array}{l}\text { PCL1500, a Tn5lacZ (Lam et al. 1990) derivative of } P \text {. fluorescens WCS365 harboring the empty vector } \\
\text { pWTT2081, which is stable in the rhizosphere (van der Bij et al. 1996). }\end{array}$ \\
\hline PCL1510 & lacZ derivative of $P$. fluorescens $\mathrm{F} 113$ (this article). \\
\hline PCL1511 & lacZ derivative of $P$. fluorescens F113 harboring the empty vector pWTT2081 (this article). \\
\hline PCL1512 & $\begin{array}{l}\text { Derivative of biocontrol strain } P \text {. fluorescens F113, which harbors the sss-containing plasmid pMP5215 } \\
\text { (this article). }\end{array}$ \\
\hline PCL1516 & lacZ derivative of $P$. fluorescens WCS307 harboring the empty vector pWTT2081 (this article). \\
\hline PCL1517 & P. fluorescens WCS307 harboring the sss-containing plasmid pMP5215 (this article). \\
\hline \multicolumn{2}{|l|}{ Escherichia coli } \\
\hline DH5 $\alpha$ & $\begin{array}{l}\text { EndAl gyrSA96 hrdR17( } r K \text { - } m K \text {-) supE44 recAl. Used for transformation and propagation of plasmids } \\
\text { (Boyer and Roulland-Dussoix 1969). }\end{array}$ \\
\hline \multicolumn{2}{|r|}{ 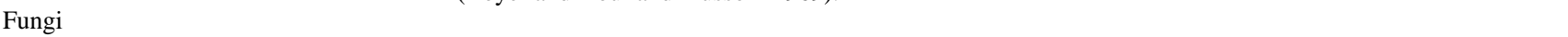 } \\
\hline $\begin{array}{l}\text { Fusarium oxysporum f. sp. radicis- } \\
\text { lycopersici strain ZUM2407 }\end{array}$ & Cause of tomato foot and root rot, IPO-DLO, Wageningen, The Netherlands. \\
\hline \multicolumn{2}{|l|}{ Plasmids } \\
\hline pRK2013 & Helper plasmid for triparental mating (Ditta et al. 1980). \\
\hline pWTT2081 & Plasmid stably maintained in the rhizosphere (van der Bij et al. 1996). \\
\hline pMP4641 & Stable plasmid pME6010 (Heeb et al. 2000) containing the ecfp gene. \\
\hline pMP4655 & Stable plasmid pME6010 (Heeb et al. 2000) containing the egfp gene. \\
\hline pMP4658 & Stable plasmid pME6010 (Heeb et al. 2000) containing the eyfp gene. \\
\hline pMP4662 & Stable plasmid pME6010 (Heeb et al. 2000) containing the DsRed gene. \\
\hline pMP5215 & $\begin{array}{l}\text { Plasmid pWTT2081 harboring the 5-kb HindIII-HindIII sss-containing DNA fragment of P. fluorescens strain } \\
\text { WCS365 which is able to complement the sss mutation in mutant PCL1233 (Dekkers et al. 1998b). }\end{array}$ \\
\hline
\end{tabular}


crocolonies gradually decreased in the direction of the root tip, on which low numbers of cells were found (Fig. 1). On the upper part of the root system, larger microcolonies were observed. The microcolonies were of both mixed and one cell type (Fig. 1A and B). On the middle part of the root (3 to $7 \mathrm{~cm}$ from the top), small microcolonies and single cells were observed. Most microcolonies were of one cell type, although a mixed microcolony occasionally was present (Fig. 1D and F). On the root tip, single cells or small groups of cells (two to four) often were observed. These small microcolonies are predominantly of one cell type (data not shown). Starting seed inoculation with equal numbers of cells of WCS365 and PCL1391, microcolonies consisting of WCS365 cells were found approximately five times more abundantly than microcolonies consisting of PCL1391 cells, especially on the middle part of the root (Fig. 1D). In contrast, root hairs were colonized almost exclusively with PCL1391 cells (Fig. 1E). Equal but very low numbers of WCS365 and PCL1391 cells were found on the root tip (data not shown).

Quorum sensing plays a crucial role in the production of phenazine-1-carboxamide (PCN) by PCL1391 (T. F. C. ChinA-Woeng, D. van den Broek, G. de Voer, K. M. G. M. van der Drift, J. E. Thomas-Oates, B. J. J. Lugtenberg, and G. V. Bloemberg, unpublished data), and PCN is crucial for biocontrol by this strain (Chin-A-Woeng et al. 1998); therefore, we wondered what the effect would be on biocontrol of the observed dilution of PCL1391 cells with WCS365 cells, which do not produce detectable acylhomoserine lactones ( $\mathrm{T}$. F. C. Chin-A-Woeng, unpublished data). The presence of WCS365 cells also dilutes the quorum sensing signals, especially on the upper parts of the root. The results of four experiments (Table 3) show that inoculation with either PCL1391 or WCS365 was significant in only two out of four experiments. In contrast, in all four experiments of mixed inoculation, significant biocontrol was observed.

\section{Effect of colonization on biocontrol by WCS365.}

Recently, it was shown in our laboratory that root colonization is a requirement for biocontrol by $P$. chlororaphis strain PCL1391 (Chin-A-Woeng et al. in press), which exerts its biocontrol action through the production of phenazine-1carboxamide (Chin-A-Woeng et al. 1998). In order to see whether the same applies for biocontrol by $P$. fluorescens strain WCS365, which acts through ISR, biocontrol activity of colonization mutants of the latter strain was compared with that of the parental strain. The tested colonization mutants were mutant PCL1210, mutated in a two-component system (Dekkers et al. 1998a); mutant PCL1233, which lacks a sitespecific recombinase (Dekkers et al. 1998b); mutant PCL1209, which lacks the O-antigen of lipopolysaccharide [LPS] (Dekkers et al. 1998c); and the nonmotile mutant PCL1269. In all seven experiments, the wild-type strain WCS365 showed significant biocontrol (Table 4). Of the tested colonization mutants, strain PCL1209 consistently caused biocontrol. The other three mutants caused biocontrol in some, but not all, experiments (Table 4).

\section{Effect of extra copies of the sss-containing colonization operon on competitive root tip colonization of Pseudomonas wild-type strains.}

In a second attempt to test a role of colonization genes in the biocontrol ability of strain WCS365, we increased the copy num- ber of the sss-containing colonization operon by incorporation of this DNA fragment into the rhizosphere-stable plasmid pWTT2081 (four to eight copies). The increase in copy number had no significant effect on the competitive colonization ability of P. fluorescens WCS365 (Table 5). however, the increase in copy number resulted in a statistically significant 8- to 16-fold increase in the colonization ability of $P$. fluorescens F113 (Table 5) and even in a 13- to 40-fold increase for $P$. fluorescens WCS307 (Table 5). Strains WCS307 and F113 contain DNA fragments that hybridize with the sss-containing fragment of WCS365. We explain the result by assuming that the majority of the cells of WCS365 are in the rhizosphere-competent state, in contrast to the situation in the other two strains. Multiple copies would result in an equilibrium situation and, therefore, cause poorer colonization of WCS365 and better colonization of the other two strains.

\section{DISCUSSION}

Biocontrol experiments performed in an F. oxysporum f. sp. radicis-lycopersici-tomato system showed that disease suppression by $P$. fluorescens WCS365 was statistically significant to a similar extent as P. chlororaphis strain PCL1391 (Table 2). These results show that WCS365 not only is an excellent colonizer but also an excellent biocontrol strain. P. fluorescens WCS365 is not antagonistic against phytopathogenic fungi under laboratory conditions; therefore, the mechanism underlying biocontrol is likely to be of another nature. Indeed, it has been reported that $P$. fluorescens strain WCS365 can induce ISR in A. thaliana ecotype Columbia, which thereby is protected against the pathogen $P$. syringae pv. tomato (Gerrits and Weisbeek 1996). Whether ISR is also responsible for biocontrol in the $F$. oxysporum f. sp. radicis-lycopersici-tomato system is not known with certainty.

Table 2. Biocontrol activity of Pseudomonas fluorescens WCS365 and P. chlororaphis PCL1391 in a Fusarium oxysporum f. sp. radicislycopersici-tomato system ${ }^{\mathrm{z}}$

\begin{tabular}{lccc}
\hline & \multicolumn{3}{c}{ Diseased plants (\%) } \\
\cline { 2 - 4 } Treatment & Exp. 1 & Exp. 2 & Exp. 3 \\
\hline Untreated control & $45 \mathrm{a}$ & $43 \mathrm{a}$ & $72 \mathrm{a}$ \\
WCS365 & $19 \mathrm{~b}$ & $25 \mathrm{~b}$ & $39 \mathrm{~b}$ \\
PCL1391 & $21 \mathrm{~b}$ & $27 \mathrm{~b}$ & $38 \mathrm{~b}$ \\
\hline
\end{tabular}

${ }^{\mathrm{z}}$ Data are the result of eight replicates of 12 plants each. Data were analyzed for significance using analysis of variance followed by Fischer's least significant difference test $(\alpha=0.05)$, using SPSS software (SPSS Inc., Chicago). Values followed by different letters indicate a statistically significant difference.

Table 3. Comparison of mixed and single inoculation of tomato with Pseudomonas fluorescens WCS365 and P. chlororaphis PCL1391 on tomato foot and root rot $^{\mathrm{z}}$

\begin{tabular}{lcccc}
\hline & \multicolumn{4}{c}{ Diseased plants (\%) } \\
\cline { 2 - 5 } Treatment & Exp. 1 & Exp. 2 & Exp. 3 & Exp. 4 \\
\hline Untreated control & $69 \mathrm{a}$ & $60 \mathrm{a}$ & $61 \mathrm{a}$ & $50 \mathrm{a}$ \\
PCL1391 & $52 \mathrm{ab}$ & $41 \mathrm{~b}$ & $47 \mathrm{bc}$ & $47 \mathrm{a}$ \\
WCS365 & $58 \mathrm{ab}$ & $35 \mathrm{~b}$ & $35 \mathrm{~cd}$ & $54 \mathrm{a}$ \\
PCL1391/WCS365 & $45 \mathrm{~b}$ & $45 \mathrm{~b}$ & $25 \mathrm{~d}$ & $33 \mathrm{~b}$ \\
\hline
\end{tabular}

${ }^{\mathrm{z}}$ Data are the result of eight replicates of 12 plants each. Data were analyzed for significance using analysis of variance followed by Fischer's least significant difference test $(\alpha=0.05)$, using SPSS software (SPSS Inc., Chicago). Values followed by different letters indications indicate a statistically significant difference. 

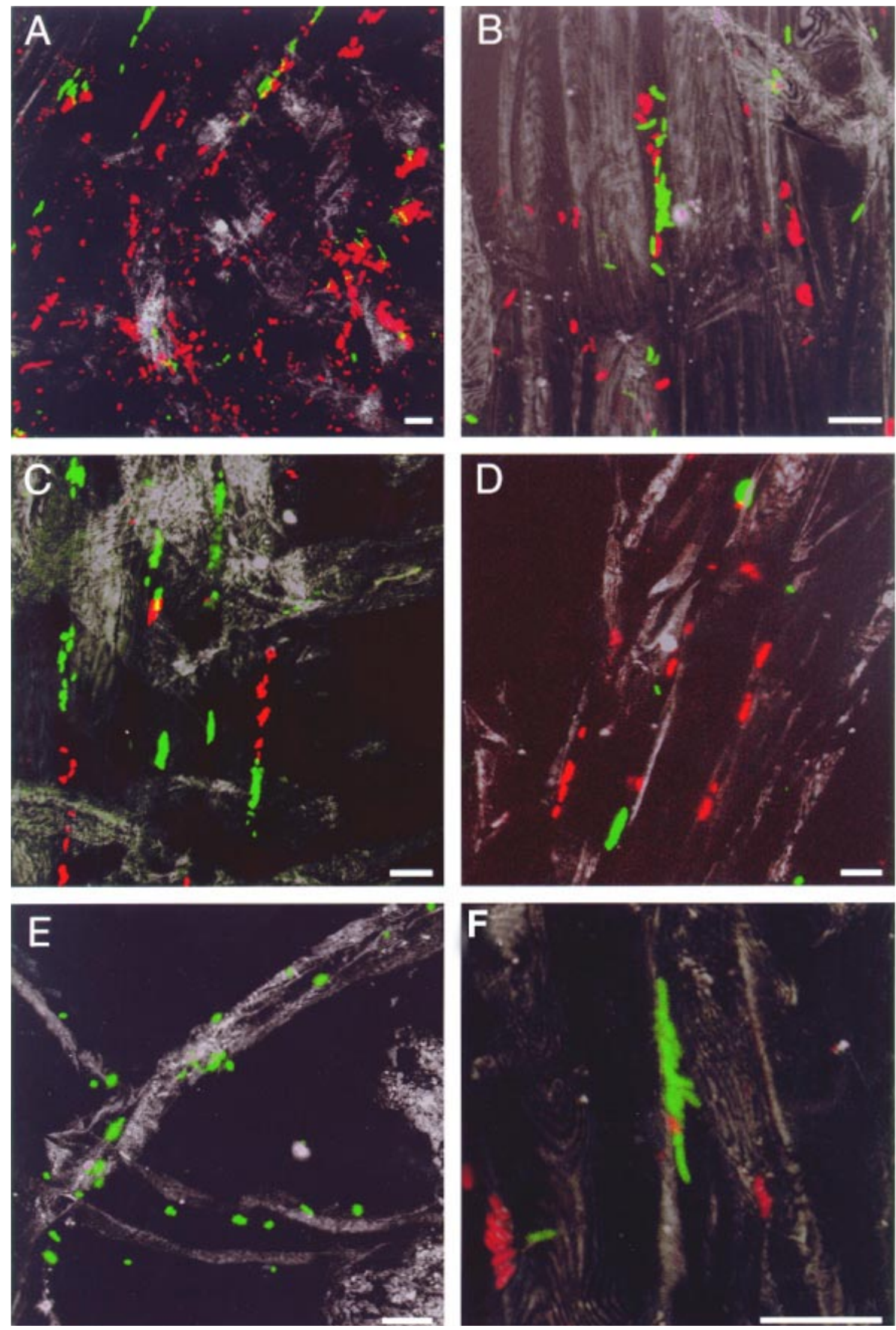
To test how two Pseudomonas biocontrol strains, which use different mechanisms of action, behave on the root upon inoculation of the seedlings with a 1:1 mixture of cells of these strains, the two cell types were labeled with different fluorescent markers. The results (Fig. 1) show that, although the strains use similar overall colonization strategies (Chin-AWoeng et al. 1997), their precise behavior differs. Cells of strain WCS365 were more abundant at the middle part of the root (Fig. 1D), whereas cells of PCL1391 were more abundant on root hairs (Fig. 1E). Another striking observation was the frequent occurrence of microcolonies of a single cell type, especially at the lower part of the root system. This suggests to us that initial colonization of new root parts occurs predominantly by single cells.

Mixed inoculation with the two cell types tended to give slightly better protection against the disease than single inoculation with the same number of cells (Table 3 ). Production of PCN by strain PCL1391 is subject to quorum sensing (T. F. C. Chin-A-Woeng, D. van den Broek, G. de Voer, K. M. G. M. van der Drift, J. E. Thomas-Oates, B. J. J. Lugtenberg, and G. V. Bloemberg, unpublished data). Although it is not known how many cells are required to allow PCN production, the fact that most microcolonies on the lower root parts consist of one cell type (Fig. 1) may contribute to the slight synergistic effect of the two strains in plant protection (Table 3).

Although an important role for colonization in biocontrol was suggested previously (Bull et al. 1991; Schippers et al. 1987), this notion is not general (Roberts et al. 1994). Now that well-characterized colonization-impaired mutants are available (Dekkers et al. 1998a, 1998b, 1998c; Lugtenberg and Dekkers 1999; Lugtenberg et al. 1996; Simons et al. 1996, 1997; Weller 1988) it is possible to test the influence of colonization on biocontrol experimentally.

Chin-A-Woeng et al. (Chin-A-Woeng et al. in press) have constructed colonization mutants in $P$. chlororaphis strain PCL1391 whose PCN production is required for biocontrol of tomato foot and root rot. Individual derivatives of this strain, impaired in sss/xerC, motility, and the synthesis of the amino acid phenylalanine, appeared not to be able to control disease in an $F$. oxysporum f. sp. radicis-lycopersici-tomato biocontrol system. Controls show that the mutants were still able to inhibit growth of $F$. oxysporum f. sp. radicis-lycopersici on plates. Their results clearly showed, for the first time, the crucial role of colonization in biocontrol (Chin-A-Woeng et al. in press).

Colonization mutants of strain WCS365 show a less clear effect (Table 4), because some mutant strains (e.g., PCL1269, PCL1233, and PCL1210) show efficient biocontrol in some, but not all, experiments, whereas strain PCL1209 shows biocontrol in all three experiments. We conclude that colonization plays a less important role in biocontrol when strain WCS365 is used than when strain PCL1391 is used. The most likely explanation is the difference in biocontrol mechanisms used by the two strains. In the case of PCL1391, production and secretion of the antifungal metabolite $\mathrm{PCN}$ on a substantial part of the root during the whole plant growth period is likely to be necessary to protect the root against pathogens from the soil. In the case of WCS365, which is supposed to act through ISR, it is conceivable that colonization of seedlings for a brief period is sufficient to induce ISR in the whole plant.

Colonization is often the limiting step in biocontrol; therefore, the importance of the sss gene in colonization (Dekkers et al. 1998b) raised the question of whether this operon can be used to improve colonization in other Pseudomonas spp. Results (Table 5) show that the presence of multiple copies of an sss-containing fragment in the wild-type strain WCS365 has no positive effect on root tip colonization. However, the presence of the same fragment in two P. fluorescens strains, F113 and WCS307, improved root tip colonization enormously. These experiments show that improvement of colonization through genetic engineering is a realistic goal. This suggests that, in cases in which colonization is limiting for biocontrol, the use of $\mathrm{col}$ genes can improve disease control.

\section{MATERIALS AND METHODS}

Bacterial strains, plasmids, and culture conditions.

All Pseudomonas strains (Table 1) were grown overnight at $28^{\circ} \mathrm{C}$ on solidified King's medium B (King et al. 1954) or in

Fig. 1. Tomato root colonization by Pseudomonas fluorescens WCS365 and P. chlororaphis PCL1391. Germinated seedlings were inoculated with a 1:1 mixture of P. fluorescens WCS365 harboring pMP4662 (DsRed) or pMP4641 (ecfp) and P. chlororaphis PCL1391 harboring pMP4655 (egfp) or pMP4658 (eyfp). Root samples (10 cm long) were inspected after 7 days of growth in the gnotobiotic system (Simons et al. 1996). A and B, Examples of the upper part of the tomato root system or root base (first 1 to $3 \mathrm{~cm}$ ). C and D, Examples of the middle part of the root system $(3$ to $7 \mathrm{~cm})$. E, Root hairs and $\mathbf{F}$, close up of two microcolonies on the middle part $(3.5 \mathrm{~cm})$ of the tomato root system. A, D, and E, A combination of DsRed-marked WCS365 and EGFP-marked PCL1391 cells. B, C, and F, A combination of ECFP-marked WCS365 and EYFP-marked PCL1391 cells. A-F, WCS365 cells are depicted in red and PCL1391 cells are depicted in green. A-F, The size bars represent $10 \mu \mathrm{m}$.

Table 4. Biocontrol activity of Pseudomonas fluorescens $\mathrm{WCS} 365$ and its colonization mutants ${ }^{\mathrm{Z}}$

\begin{tabular}{|c|c|c|c|c|c|c|c|}
\hline \multirow[b]{2}{*}{ Inoculated strain } & \multicolumn{7}{|c|}{ Diseased plants (\%) } \\
\hline & Exp. 1 & Exp. 2 & Exp. 3 & Exp. 4 & Exp. 5 & Exp. 6 & Exp. 7 \\
\hline None & $42 \mathrm{a}$ & $37 \mathrm{a}$ & $63 \mathrm{a}$ & $46 a$ & $45 \mathrm{a}$ & $43 \mathrm{a}$ & $72 \mathrm{a}$ \\
\hline WCS365 & $26 \mathrm{c}$ & $21 \mathrm{~b}$ & $44 \mathrm{~b}$ & $36 \mathrm{~b}$ & $19 \mathrm{~b}$ & $25 \mathrm{~b}$ & $39 \mathrm{bc}$ \\
\hline PCL1269 & $\ldots$ & $\ldots$ & $\ldots$ & $\ldots$ & $\ldots$ & $36 \mathrm{a}$ & $42 \mathrm{bc}$ \\
\hline PCL1209 & $\ldots$ & $\ldots$ & $\ldots$ & $\ldots$ & $16 \mathrm{~b}$ & $26 \mathrm{~b}$ & $51 \mathrm{~b}$ \\
\hline PCL1233 & $35 \mathrm{abc}$ & $23 \mathrm{~b}$ & $58 \mathrm{a}$ & $47 \mathrm{a}$ & $16 \mathrm{~b}$ & $30 \mathrm{a}$ & $47 \mathrm{bc}$ \\
\hline PCL1210 & $33 \mathrm{ab}$ & $\ldots$ & $\ldots$ & $45 \mathrm{ab}$ & $20 \mathrm{~b}$ & $27 \mathrm{~b}$ & $37 \mathrm{c}$ \\
\hline
\end{tabular}

${ }^{\mathrm{z}}$ Data are the result of eight replicates of 12 plants each. It should be noted that the methods used for seed inoculation in experiments 1 through 4 and 5 through 7 were different. Data were analyzed for significance using analysis of variance followed by Fischer's least significant difference test $(\alpha=$ 0.05), using SPSS software (SPSS Inc., Chicago). Values with different letter indications indicate a statistically significant difference. 
liquid King B under vigorous aeration. For the transfer of plasmids from Escherichia coli to Pseudomonas spp., triparental mating was performed using pRK2013 as the helper plasmid (Ditta et al. 1980). Selection for plasmid pWTT2081 and its derivatives (van der Bij et al. 1996) was performed on medium supplemented with nalidixic acid and tetracycline to final concentrations of 15 and $80 \mu \mathrm{g} / \mathrm{ml}$, respectively. E. coli cells used for propagation of plasmids were grown overnight in liquid or solidified Luria-Bertani medium (LB) (Sambrook et al. 1989) supplemented with tetracycline $(40 \mu \mathrm{g} / \mathrm{ml})$. If appropriate, $\mathrm{X}$-gal (5-bromo-4-chloro-3-indolyl- $\beta$-D-galactoside) was added to the medium to a final concentration of $40 \mu \mathrm{g} / \mathrm{ml}$ as an indicator for $\beta$-galactosidase activity.

\section{Colonization experiments on tomato plants.}

The ability of various Pseudomonas strains to colonize tomato root tips was studied using the gnotobiotic system described by Simons et al. (1996). Briefly, sterile germinated tomato seeds were inoculated with a 1:1 mixture of cells of two strains, one of which was marked with Tn5lacZ. After growth for 7 days, bacteria were isolated from the root tip (1 to $2 \mathrm{~cm}$ ). When plasmid-containing strains had to be tested, pWTT2081, a rhizosphere-stable plasmid (van der Bij et al. 1996), was used as the vector. This plasmid acts as a genetic or physiological burden (van der Bij et al. 1996); therefore, it also was present in the control cells. The ratio of cells harboring plasmid pMP5215 (yellow/white colonies) and cells marked with Tn5lacZ and additionally harboring plasmid pWTT2081 (blue colonies) was determined by plating on King B supplemented with X-gal.

\section{Biocontrol experiments.}

For experiments 1 through 4 (Table 4), suspensions of approximately $10^{12} \mathrm{CFU} / \mathrm{ml}$ were made by scraping Pseudomonas bacteria from King B plates and suspending them into $6 \mathrm{ml}$ of sterile $10 \mathrm{mM} \mathrm{MgSO}$. These suspensions were used to coat seeds of tomato (Lycopersicon esculentum Mill. cv. Carmello) in a small-scale industrial fluidized bed coater. For all other seed coatings performed for biocontrol experiments,

Table 5. Effect of the introduction of the sss-containing plasmid pMP5215 on the competitive tomato root tip-colonizing ability of various Pseudomonas fluorescens wild-type strains ${ }^{y}$

\begin{tabular}{lcc}
\hline & \multicolumn{2}{c}{ Colonizing ability $^{\mathbf{z}}$} \\
\cline { 2 - 3 } Strain & Wild-type & Wild-type harboring plasmid pMP5215 \\
\hline WCS365 & $4.4 \pm 0.4 \mathrm{a}$ & $3.8 \pm 0.5 \mathrm{a}$ \\
F113 & $3.3 \pm 0.8 \mathrm{a}$ & $4.5 \pm 0.3 \mathrm{~b}$ \\
& $3.7 \pm 0.3 \mathrm{a}$ & $4.6 \pm 0.4 \mathrm{~b}$ \\
& & $4.6 \pm 0.2 \mathrm{~b}$ \\
WCS307 & $3.0 \pm 0.9 \mathrm{a}$ & $4.4 \pm 0.3 \mathrm{~b}$ \\
\hline
\end{tabular}

${ }^{y}$ In these experiments, lacZ-marked wild-type strains containing the empty vector pWTT2081 were compared with the wild-type strain containing pMP5215 (i.e., pWTT2081), in which an sss-containing fragment (Dekkers et al. 1998b) has been cloned. It was shown previously (Simons et al. 1996; van der Bij et al. 1996) that the presence of this lac $Z$ marker has no influence on the colonizing behavior of WCS365.

${ }^{\mathrm{z}}$ Mean $\log _{10}(\mathrm{CFU}+1) / \mathrm{cm}$ of root tip. Different letters following colonization values within one experiment indicate that the results are significantly different at $P=0.05$ according to the Wilcoxon MannWhitney test (Sokal and Rohlf 1981). overnight King B cultures were washed and adjusted to an optical density at $620 \mathrm{~nm}\left(\mathrm{OD}_{620}\right)$ of 0.7 . For coating with a mixture of both WCS365 and PCL1391, cultures of OD $_{620}$ of 0.7 were mixed in a ratio of $1: 1$. All suspensions were mixed with an equal volume of $2 \%$ (wt/vol) methylcellulose. Tomato seeds were inoculated by dipping in the resulting suspensions for $10 \mathrm{~min}$ and air-dried. Biocontrol by various Pseudomonas spp. against $F$. oxysporum f. sp. radicis-lycopersici on tomato was performed as described by Chin-A-Woeng et al. (1998). Coated tomato seeds were sown in $F$. oxysporum-infested soil in multicell trays. For each coating, at least eight replications containing 12 plants each were used. After incubation for 16 days in a climate-controlled growth chamber at $20^{\circ} \mathrm{C}$ and $85 \%$ relative humidity, the number of diseased root systems was assessed. Data were analyzed for significance using analysis of variance followed by Fischer's least significant difference test $(\alpha=0.05)$, using SPSS software (SPSS Inc., Chicago).

\section{Microscopy.}

Germinated tomato seedlings were inoculated with a $1: 1$ mixture of $P$. fluorescens WCS365, harboring the DsRed-or ecfp-containing plasmid, and P. chlororaphis PCL1391, harboring egfp- or eyfp-containing plasmid, and planted in the gnotobiotic system (Simons et al. 1996). After 1 week, the tomato roots were isolated and rinsed in phosphate-buffered saline solution (PBS; $0.9 \% \mathrm{NaCl}$ buffered with $10 \mathrm{mM}$ sodium phosphate, $\mathrm{pH}$ 7.2). Tomato roots were mounted on a microscope slide for observation. Roots were examined with an inverted fluorescence microscope (Leica DMIRBE; Leica, Bensheim, Germany) equipped with filter blocks with spectral properties matching those of CFP (440/21-nm excitation, 480/36-nm emission, XF114; Chroma, Brattleboro, VT, U.S.A.) or EGFP and EYFP (470/20-nm excitation, 515-nm long pass emission, I3; Leica) or DsRed (538/22-nm excitation, 590-nm long pass emission, N2.1; Leica). A Leica SP confocal scanhead was attached to this microscope. Dual color images were obtained by sequentially scanning with settings optimal for CFP (excitation with the 457-nm argon laser line, detection of emitted light between 470 and $490 \mathrm{~nm}$ ), EGFP (excitation with a 488-nm argon laser line, detection of emitted light between 500 and $520 \mathrm{~nm}$ ), EYFP (excitation with the 488-nm argon laser line, detection of emitted light between 530 and $550 \mathrm{~nm}$ ), or DsRed (excitation with the 568-nm krypton laser line, detection of the emitted light between 580 and $620 \mathrm{~nm}$.) Cross talk between the channels in this set-up was monitored and, in all cases, was negligible. Pictures obtained using different channels were merged using Photoshop 5.0 (Adobe, San Jose, CA, U.S.A.) to facilitate projection.

\section{ACKNOWLEDGMENTS}

We thank B. A. M. Kroon and R. J. Scheffer of Novartis Seeds B.V. (Enkhuizen, The Netherlands) for performing experiments 1 through 4 of Table 4; and Davy de Witt for his help with biocontrol experiments. C. C. P. was supported by the NWO-LNV Priority Program Crop Protection, project number 805.45 .008 . The investigations were partly supported by the EU program BIO4-CT98-0254.

\section{LITERATURE CITED}

Bloemberg, G. V., Wijfjes, A. H. M., Lamers, G. E. M., Stuurman, N., and Lugtenberg, B. J. J. Simultaneous imaging of Pseudomonas fluorescens WCS365 populations expressing three different autofluores- 
cent proteins in the rhizosphere: New perspectives for studying microbial communities. Mol. Plant-Microbe Interact. In press.

Boyer, H. W., and Roulland-Dussoix, D. 1969. A complementation analysis of the restriction and modification of DNA in Escherichia coli. J. Mol. Biol. 41:459-472.

Brand, J., Lugtenberg, B. J. J., Glandorf, D. C. M., Bakker, P. A. H. M., Schippers, B., and de Weger, L. A. 1991. Isolation and characterization of a superior potato root-colonizing Pseudomonas strain. Pages 350-354 in: Plant Growth-Promoting Rhizobacteria-Progress and Prospects. C. Keel, B. Knoller, and G. Défago, eds. IOBC/WPRS Bull. XIV-8. Interlaken, Switzerland.

Bull, C. T., Weller, D. M., and Thomashow, L. S. 1991. Relationship between root colonization and suppression of Gaeumannomyces graminis var. triciti by Pseudomonas fluorescens strain 2-79. Phytopathology 81:954-959.

Chin-A-Woeng, T. F. C., Bloemberg, G. V., Mulders, I. H. M., Dekkers, L. C., and Lugtenberg, B. J. J. Root colonization by phenazine-1carboxamide-producing bacterium Pseudomonas chlororaphis PCL1391 is essential for biocontrol of tomato foot and root rot. Mol Plant-Microbe Interact. In press.

Chin-A-Woeng, T. F. C., Bloemberg, G. V., van der Bij, A. J., van der Drift, K. M. G. M., Schripsema, J., Kroon, B., Scheffer, R. J., Keel, C., Bakker, P. A. H. M., Tichy, H., de Bruijn, F. J., Thomas-Oates, J. E., and Lugtenberg, B. J. J. 1998. Biocontrol by phenazine-1carboxamide-producing Pseudomonas chlororaphis PCL1391 of tomato root rot caused by Fusarium oxysporum f. sp. radicislycopersici. Mol. Plant-Microbe Interact. 11:1069-1077.

Chin-A-Woeng, T. F. C., de Priester, W., van der Bij, A. J., and Lugtenberg, B. J. J. 1997. Description of the colonization of a gnotobiotic tomato rhizosphere by Pseudomonas fluorescens biocontrol strain WCS365, using scanning electron microscopy. Mol. Plant-Microbe Interact. 10:79-86

Colloms, S. D., Sykora, P., Szatmari, G., and Sherratt, D. J. 1990. Recombination at ColE1 cer requires the Escherichia coli xerC gene product, a member of the lambda integrase family of site-specific recombinases. J. Bacteriol. 172:6973-6980.

Dekkers, L. C., Bloemendaal, C. J. P., de Weger, L. A., Wijffelman, C. A., Spaink, H. P., and Lugtenberg, B. J. J. 1998a. A two-component system plays an important role in the root-colonizing ability of Pseudomonas fluorescens strain WCS365. Mol. Plant-Microbe Interact. 11:45-56.

Dekkers, L. C., Phoelich, C. C., van der Fits, L., and Lugtenberg, B. J. J. 1998b. A site-specific recombinase is required for competitive root colonization by Pseudomonas fluorescens WCS365. Proc. Natl. Acad. Sci. USA 95:7051-7056.

Dekkers, L. C., van der Bij, A. J., Mulders, I. H. M., Phoelich, C. C., Wentwoord, R. A. R., Glandorf, D. C. M., Wijffelman, C. A., and Lugtenberg, B. J. J. 1998c. Role of the O-antigen of lipopolysaccharide, and possible roles of growth rate and NADH:ubiquinone oxidoreductase (пио) in competitive tomato root-tip colonization by Pseudomonas fluorescens WCS365. Mol. Plant-Microbe Interact. 11:763-771.

Ditta, G., Stanfield, S., Corbin, D., and Helinski, D. R. 1980. Broad host range DNA cloning system for Gram-negative bacteria: Construction of a gene bank of Rhizobium meliloti. Proc. Natl. Acad. Sci. USA 77:7347-7351.

Dorman, C. J., and Higgins, C. F. 1987. Fimbrial phase variation in Escherichia coli: Dependence on the integration host factor and homologies with other site-specific recombinases. J. Bacteriol. 169:3840-3843.

Geels, F. P., and Schippers, B. 1983a. Selection of antagonistic fluorescent Pseudomonas spp. and their root colonization and persistence following treatment of seed potatoes. Phytopathol. Z. 108:193-206.

Geels, F. P., and Schippers, B. 1983b. Reduction of yield depressions in high frequency potato cropping soil after seed tuber treatments with antagonistic fluorescent Pseudomonas spp. Phytopathol. Z. 108:207-214.

Gerrits, J. P. L., and Weisbeek, P. J. 1996. Induction of systemic ac- quired resistance by saprophytic Pseudomonas spp. in the model plant Arabidopsis thaliana. Pages 13-14 in: NWO-LNV Priority Program Crop Protection Progress Report. Lunteren, The Netherlands.

Glandorf, D. C. M. 1992. Root colonization by fluorescent pseudomonads. Ph.D. thesis. University of Utrecht, Utrecht, The Netherlands.

Heeb, S., Itoh, Y., Nishijyo, T., Schnider, U., Keel, C., Wade, J., Walsh, U., O'Gara, F., and Haas, D. 2000. Small, stable shuttle vectors based on the minimal pVS1 replicon for use in gram-negative, plantassociated bacteria. Mol. Plant-Microbe Interact. 13:232-237.

Höfte, M., Dong, Q., Kourambas, S., Krishnapillai, V., Sherratt, D., and Mergeay, M. 1994. The sss gene product, which affects pyoverdin production in Pseudomonas aeruginosa 7NSK2, is a site-specific recombinase. Mol. Microbiol. 14:1011-1020.

King, E. O., Ward, M. K., and Raney, D. E. 1954. Two simple media for the demonstration of pyocyanin and fluorescin. J. Lab. Clin. Med. 44:301-307.

Klemm, P. 1986. Two regulatory fim genes, fimB and fimE, control the phase variation of type 1 fimbriae in Escherichia coli. EMBO J. 5:1389-1393

Lam, S. T., Ellis, D. M., and Ligon, J. M. 1990. Genetic approaches for studying rhizosphere colonization. Plant Soil 129:11-18.

Lugtenberg, B., van der Bij, A. J., Bloemberg, G. V., Chin-A-Woeng, T., Dekkers, L., Kravchenko, L., Mulders, I., Phoelich, C., Simons, M., Spaink, H., Tikhonovich, I., de Weger, L., and Wijfelman, C. 1996. Molecular basis of rhizosphere colonization by Pseudomonas bacteria. Pages 433-440 in: Biology of Plant-Microbe Interactions. G. Stacey, B. Mullin, and P. M. Gresshoff, eds. Int. Soc. Mol. PlantMicrobe Interact., St Paul, MN.

Lugtenberg, B. J. J., and Dekkers, L. C. 1999. What makes Pseudomonas bacteria rhizosphere competent? Environ. Microbiol. 1:9-13.

Lugtenberg, B. J. J., Dekkers, L. C., Bansraj, M., Bloemberg, G. V., Camacho, M., Chin-A-Woeng, T. F. C., van den Hondel, K., Kravchenko, L., Kuiper, I., Lagopodi, A., Mulders, I., Phoelich, C., Ram, A., Tikhonovich, I., Tuinman, S., and Wijfjes, A. Pseudomonas genes and traits involved in tomato root colonization. In: Proc. Int. Congr. Mol. Plant-Microbe Interact, 9th. In press.

Roberts, D. P., Short, N. M., Maloney, A. P., Nelson, E. B., and Schaff, D. A. 1994. Role of colonization in biocontrol: studies with Enterobacter cloacae. Plant Sci. 101:83-89.

Sambrook, J., Fritsch, E. F., and Maniatis, T. 1989. Molecular Cloning: A Laboratory Manual. 2nd ed. Cold Spring Harbor Laboratory, Cold Spring Harbor, NY, U.S.A.

Schippers, B., Bakker, A. W., and Bakker, P. A. H. M. 1987. Interactions of deleterious and beneficial rhizosphere microorganisms and the effect of cropping practices. Annu. Rev. Phytopathology 25:339-358.

Schroth, M. N., and Hancock, J. G. 1982. Disease-suppressive soil and root-colonizing bacteria. Science 216:1376-1381.

Shanahan, P., O'Sullivan, D. J., Simpson, P., Glennon, J. D., and O'Gara, F. 1992. Isolation of 2,4-diacetylphloroglucinol from a fluorescent pseudomonad and investigations of physiological parameters influencing its production. Appl. Environ. Microbiol. 58:353-358.

Simons, M., Permentier, H. P., de Weger, L. A., Wijffelman, C. A., and Lugtenberg, B. J. J. 1997. Amino acid synthesis is necessary for tomato root colonization by Pseudomonas fluorescens strain WCS365. Mol. Plant-Microbe Interact. 10:102-106.

Simons, M., van der Bij, A. J., Brand, J., de Weger, L. A., Wijffelman, C. A., and Lugtenberg, B. J. J. 1996. Gnotobiotic system for studying rhizosphere colonization by plant growth-promoting Pseudomonas bacteria. Mol. Plant-Microbe Interact. 9:600-607.

Sokal, R. R., and Rohlf, F. J. 1981. Biometry. Freeman, San Francisco. van der Bij, A. J., de Weger, L. A., Tucker, W. T., and Lugtenberg, B. J. J. 1996. Plasmid stability in Pseudomonas fluorescens in the rhizosphere. Appl. Environ. Microbiol. 62:1076-1080.

Weller, D. M. 1988. Biological control of soilborne plant pathogens in the rhizosphere with bacteria. Annu. Rev. Phytopathology 26:379-407. 